FABRICAÇÃO E TESTE DO NÍVEL INTERMEDIÁRIO DE FILTROS DE DESFLUORIZAÇÃO BASEADOS EM ALUMINA ATIVADA

\title{
FABRICATION AND TESTING OF INTERMEDIATE LEVEL ACTIVATED ALUMINA BASED DEFLUORIDATION FILTERS
}

\author{
AGRAWAL, $\mathrm{R}^{1}$; MARGANDAN, $\mathrm{K}^{1}$; SINGH, $\mathrm{K}^{1}$; ACHARYA, $\mathrm{R}^{2}$; SHARMA, $\mathrm{S}^{1}$; QANUNGO, $\mathrm{K}^{1 *}$ \\ ${ }^{1}$ Department of Applied Science \& Humanities, \\ Faculty of Engineering \& Technology, \\ Mody Institute of Science \& Technology (Deemed University), \\ Lakshmangarh-332311, Dist. Sikar, Rajasthan, India \\ ${ }^{2}$ Dept. of Science and Technology, Govt. of Rajasthan, \\ $506,4^{\text {th }}$ Floor Mini Secretariat \\ Bani-Park, Jaipur, Rajasthan, India \\ ${ }^{*}$ Autor correspondente \\ e-mail: kushalq@rediffmail.com
}

Received 28 March 2013; accepted 3 April 2013

\section{RESUMO}

Dois filtros de desfluorização de alta capacidade e alta taxa com 10 e $25 \mathrm{~kg}$ de alumina ativada foram fabricados e testados com água de posso local contaminada com flúor. Diversos parâmetros de qualidade da água como $\mathrm{pH}$, TDS, $\mathrm{F}^{-}, \mathrm{Cl}^{-}, \mathrm{SO}_{4}{ }^{2-}, \mathrm{NO}_{3}{ }^{-}$, dureza de $\mathrm{Ca}^{2+}$ e $\mathrm{Mg}^{2+}$ e dureza total foram monitorados através do proceso de filtração e foi detectado que esses valores estão dentro dos padrões permitidos. A performance do filtro foi avaliada através da determinação do volume de água padrão $(<1.5 \mathrm{ppm})$, capacidade de adsorção de flúor, taxa de vazão, tempo de contato, capacidade de água do filtro, tempo antes da primeira regeneração e custo do filtro. Baseado em uma discussão detalhada frente a esses parâmetros, o filtro com $10 \mathrm{~kg}$ de alumina foi considerado melhor se comparado ao de $25 \mathrm{~kg}$.

Palavras-chave: Activated Alumina, Defluoridation, Fluoride, Water Filter

\section{ABSTRACT}

Two high capacity, high flow rate defluoridation filters with 10 and 25kg Activated Alumina have been fabricated and tested with local fluoride contaminated ground water. Various water quality parameters like $\mathrm{pH}$, TDS, $\mathrm{F}^{-}, \mathrm{Cl}^{-}, \mathrm{SO}_{4}{ }^{2-}, \mathrm{NO}_{3}{ }^{-}, \mathrm{Ca}^{2+}$ Hardness, $\mathrm{Mg}^{2+}$ Hardness, Total Hardness have been monitored throughout the filtration process and it has been found that these values are within the permissible limits. The filter performance has been evaluated by determining the volume of safe water $(<1.5 \mathrm{ppm})$, fluoride uptake capacity, flow rate, empty bed contact time, water capacity of filter, time before first regeneration, capital and recurring cost of filter. On basis of detailed discussion on these parameters the filter with $10 \mathrm{~kg} \mathrm{AA}$ is considered to be a better filter as compared to the one with $25 \mathrm{~kg} \mathrm{AA}$.

Keywords: Activated Alumina, Defluoridation, Fluoride, Water Filter 


\section{INTRODUCTION}

In many parts of the world high concentration of fluoride occurs naturally in ground water and causes wide spread fluorosis, a disease which mainly affects the bones and teeth ${ }^{1-6}$. About 95\% of fluoride ingested the body is deposited in hard tissues like bones and teeth weaking their structure and making them brittle ${ }^{7,8}$. Other problems which arise due to the excessive intake of fluoride are low heamoglobin levels, excessive thirst, headache, skin rashes, nervousness, depression, gastrointestinal problems, urinary tract malfunctioning, low IQ, weakening of muscle 14. In India, excess fluoride is present in ground water in many states for example in parts of Andhra Pradesh, Rajasthan etc ${ }^{9-11}$.There are several methods of defluoridation like Precipitation Method, Nalgonda Technique, Adsorption, Ion Exchange Mechanisms etc ${ }^{12}$. Excess of fluoride in ground water have been treated using Activated alumina (AA) based defluoridation filters earlier ${ }^{13-21}$. As a part of Department of Science and Technology, Government of India sponsored project to design, develop and test, low cost defluoridation filters for rural use, we have recently studied the kinetics of fluoride removal from local ground water using $\mathrm{AA}^{22}$ and described the fabrication and testing of four small domestic fluoride level filter fitted with single or double ceramic cartridge with different quantities of $\mathrm{AA}(2.5,3,3.5 \mathrm{~kg})$ and one or two ceramic cartridges ${ }^{24,25}$.We found that the flow rate of defluoridated water from these filters was less, (2 lit./hr.) and the filter needs to be refilled 34 times at least, per day to obtain approximately 20 liter of water to meet the water needs of an average household. The AA needs to be replaced or regenerated every 2-4 months. In continuation the above study we have fabricated AA based fluoride filters with high flow rates and high capacity and was tested them in the lab using fluoride contaminated ground water from a nearby village (Bhooma Chota), and in this paper we present the results of our study.

\section{EXPERIMENTAL}

Four holes of $1 \mathrm{~cm}$ diameter were made at the bottom of a 51 liter HDPE water storage container. Four similar holes of $1 \mathrm{~cm}$ diameter were made on top lid of a 50 liter HDPE drum so that both the set of holes were centro-symmetric.
Four ceramic cartridges were fitted on the base of the top container with their outlets protruding through the holes into bottom container (fig. 1 and 2). $10 \mathrm{~kg}$ and $25 \mathrm{~kg}$ water washed activated alumina (DF-101, M/s Siddhartha Industries, Surat, and Gujarat, India) was poured from the top.

A tap was fitted $2 \mathrm{~cm}$ above the base of the bottom of drum. Fluoride contaminated ground water from the village Bhooma Chota (middle tubewell) was brought by water tankers and stored in 1000 and

500 liters drums in the lab. The water was pumped into the upper container every day. Periodically various water quality parameters were analysed as follows: Water from the outlet tap was analysed for fluoride using a Fluoride Ion Selective Electrode (Orion Thermo Scientific, USA) and TISAB III buffer. Calcium and Magnesium hardness using EDTA method, Carbonate and Bicarbonate by titrating with standardised $\mathrm{H}_{2} \mathrm{SO}_{4}$, and Chloride by titrating with silver nitrate. Sodium and Potassium were analysed by Flame Photo Meter. Duly calibrated electronic $\mathrm{pH}$ and TDS meter were used for determining $\mathrm{pH}$ and TDS of untreated and treated water.

\section{RESULTS AND DISCUSSION}

We were unable to use the same water container for both the upper and the lower chamber because of the two reasons. Firstly we found that four ceramic cartridges could not be fitted at the base of available 50 liter drum, therefore it could not be used as the top container. Secondly the 51 liter water container used had coagulated cover which could not support the weight of water filled container (approx. 53kg). Therefore the present arrangement of two different water containers has been used. In the beginning of our experiments we filled $10 \mathrm{~kg}$ activated alumina in the lower chamber after covering the inlet of the tap with layer of nylon cloth having $0.16 \mathrm{~mm}$ mesh size. We however found after one week the particles of AA choked the nylon cloth and flow of water stopped from the filter. Therefore we transferred the AA from the bottom drum to the upper container. Hence in the second filter we filled 25 $\mathrm{kg} \mathrm{AA}$ in the upper container from the beginning 
of the experiment itself (Fig 3).

The costs of the various components of the filter are given in Table 1. We found that the maximum component of cost is that of AA Rs. $1160 /-$ for $10 \mathrm{~kg}$ and Rs. $2900 /-$ for $25 \mathrm{~kg}$. The diameter of the top container was $41 \mathrm{~cm}$ at the top and base $32 \mathrm{~cm}$ at the base. The cask shaped bottom container was $30.5 \mathrm{~cm}$ at the top and $29.5 \mathrm{~cm}$ at the base in diameter.

The filter can be fabricated easily by an unskilled labor with only few drilling of holes and tightening of wing nuts of the ceramic cartridge is required. The water capacity of the filter was found to be 40 liter for $10 \mathrm{~kg}$ and 16 liter for $25 \mathrm{~kg}$ AA. The bed volume of $10 \mathrm{~kg} \mathrm{AA}$ is 13.5 lit. and $25 \mathrm{~kg} \mathrm{AA}$ is 33.78 lit. Average elution rate of defluoridated water from the filter was 20.6 lit./hr. for $10 \mathrm{~kg}$ and $9.3 \mathrm{lit} / \mathrm{hr}$ for $25 \mathrm{~kg}$ (Figure 4 and 5). This difference is partly due to the less water capacity of the filter filled with more quantity of AA and more resistance to the flow of water by $A A$ in the $25 \mathrm{~kg} \mathrm{AA}$ filter than with $10 \mathrm{~kg} \mathrm{AA}$. (Empty Bed Contact Time) EBCT for $10 \mathrm{~kg} \mathrm{AA}$ filter is $39.35 \mathrm{~min}$. and $56.3 \mathrm{~min}$. for $25 \mathrm{~kg} \mathrm{AA}$ ) Table 2.

If the $10 \mathrm{~kg}$ filter is filled once a day it produces sufficient water for two days (assuming water can supply of 20 liter/day for a family of four people). For $25 \mathrm{~kg} \mathrm{AA}$ filter needs to refill at least twice a day for two days to produce 64 liter of drinking water which is sufficient to meet drinking water requirements for three days. The fluoride concentration in treated water was monitored every 50 liters and depicted in (Fig 6 and 7 ). The volume of safe water yield $(<1.5$ ppm) of the filter with $10 \mathrm{~kg}$ is 3300 liters and 3900 liters for $25 \mathrm{~kg} \mathrm{AA}$. Specific safe water yield is $330 \mathrm{mg} \mathrm{F}-/ \mathrm{kg}$ for $10 \mathrm{~kg}, 156 \mathrm{mg} \mathrm{F}-/ \mathrm{kg} \mathrm{AA}$ for 25 $\mathrm{kg} \mathrm{AA}$. The Fluoride Uptake capacity of AA for AA in the filter with $10 \mathrm{~kg} \mathrm{AA}$ is 722.7 and 396.24 for filter with $25 \mathrm{~kg} \mathrm{AA}$.

The higher volume of safe water in $25 \mathrm{~kg}$ filter than $10 \mathrm{~kg}$ filter can be explained in the larger amount of AA. This safe water volume is not, as expected 2.5 times, that that of $25 \mathrm{~kg}$ filter. The lower specific safe water yield and hence lower fluoride uptake capacity in the filter with $25 \mathrm{~kg} \mathrm{AA}$ is ascribed to several reasons discussed as follows: a) lower than expected volume of safe water from the $25 \mathrm{~kg} \mathrm{AA}$ filter than the $10 \mathrm{~kg} \mathrm{AA}$ filter, b) the average bicarbonate concentration and the average TDS in raw ground water was $300 \mathrm{ppm}$ and 100 ppm higher, when the $25 \mathrm{~kg} \mathrm{AA}$ filter was being tested, as compared to the raw water with which $10 \mathrm{~kg} \mathrm{AA}$ filter was tested.

The overall low FUC of AA in both the filters is due to a) their relatively high flow rates (20.6 and 9.3 liter/hours) as compared with single cartridge flow rate was 1.7 lit./h and double candle filter flow rate was 3 lit. $/ h^{23,24}$ a) it is known that AA absorbs fluoride optimally at $\mathrm{pH} 5^{21,25,26,27}$ the average $\mathrm{pH}$ of ground water being used for testing the filter was 9 , and it is known that the fluoride adsorption capacity of the filter falls drastically after $\mathrm{pH} \quad 8-8.5^{27,29,30}$ c) very high concentration of bicarbonates in the raw water is also known to reduce the fluoride adsorption ${ }^{21,} 28$.

AA surface has an amphoteric character. Removal of fluoride by AA is mainly due to ionexchange and can be described by following equations

$$
\begin{array}{lll}
\mathrm{AlOH}+\mathrm{F}^{-} & \rightarrow & \mathrm{AlF}+\mathrm{OH}^{-} \\
\mathrm{AlOH}_{2+}+\mathrm{F}^{-} & \rightarrow & \mathrm{AlF}+\mathrm{H}_{2} \mathrm{O}
\end{array}
$$

Al represent solid alumina surface ${ }^{30}$.

Notice that the fluoride removal from the ground water is nearly constant till 3000 lit. in the $25 \mathrm{~kg} \mathrm{AA}$ while for the $10 \mathrm{~kg} \mathrm{AA}$ filter the fluoride level fluctuates (Fig 6 and 7). Also notice the presence of four ceramic cartridges in the filter and occupying $270 \mathrm{~cm}^{2}$ each of surface area protruding upwards from the base of the filter (Fig 2 ). Therefore the raw water comes into contact with $A A$ to different extents before coming in contact with the surface of the ceramic cartridges. In the filter with $25 \mathrm{~kg} \mathrm{AA}$, the bed volume of $\mathrm{AA}$ is 2.5 times more than with $10 \mathrm{~kg} \mathrm{AA}$ and the defluoridation is more uniform. Assuming a water usage of 20 lit. per day if used at domestic level, the $10 \mathrm{~kg}$ filter can be operated for 5 months 15 days and $25 \mathrm{~kg}$ filter can be operated for 6 months 15 days before it needs to be regenerated.

If the filter is shared at community level for example, between 5 households then the $10 \mathrm{~kg}$ AA filter can be operated for one month three days and $25 \mathrm{kgAA}$ filter for one month and nine days. Considering the higher average flow rate of $10 \mathrm{~kg} \mathrm{AA}$ filter and higher fluoride uptake capacity and specific safe water yield cost per liter of 
defluoridated water, the $10 \mathrm{~kg}$ filter is better than $25 \mathrm{~kg} \mathrm{AA}$ filter

We now discuss the other water quality parameters monitored in the raw and filtered water during the defluoridation process. The maximum permissible limit of $\mathrm{pH}$ according to BIS standard is 6.5 to $8.5^{31}$. The average $\mathrm{pH}$ of raw water is $9.03,9.18$ while for average treated water $\mathrm{pH}$ is $9.1,9.01$ for 10 and $25 \mathrm{~kg}$ (fig. 8). The average carbonate of raw water is 171.6 and $122.4 \mathrm{ppm}$ and average treated water carbonate is 194 and135ppm for $10 \mathrm{~kg}$ and $25 \mathrm{~kg}$ (fig 9). The average bicarbonate of raw water is 1349.7, $1662.8 \mathrm{ppm}$ and the average bicarbonate of treated water is 1075.6 and 1278.9 ppm (fig. 10). (The max. permissible limit for total alkalinity is 600 ppm (fig.11) ${ }^{31}$

For chloride, the permissible limit is 1000 $\mathrm{ppm}^{31}$. The average chloride of raw water is $644.2,533.45 \mathrm{ppm}$ and average chloride of treated water is 709.85 and $490.50 \mathrm{ppm}$ for 10 and $25 \mathrm{~kg}$ (fig. 12). For calcium the maximum permissible limit is $200 \mathrm{ppm}^{31}$. The average calcium of raw water is 9.6 and $10.8 \mathrm{ppm}$ and average calcium of treated water is 7.4 and 7.1 ppm for 10 and $25 \mathrm{~kg}$ (fig. 13).

For magnesium, the maximum permissible limit is $100 \mathrm{ppm}^{31}$. The average magnesium of raw water is 18.1 and $22 \mathrm{ppm}$ and the average magnesium of treated water is 13.9 and $5.1 \mathrm{ppm}$ (fig. 14). The maximum permissible limit of TDS according to BIS standard is 2000 ppm in absence of any alternative source of water ${ }^{31}$. The TDS measured (indirectly based on conductivity) of raw water. The average TDS value is 1420 and $1532 \mathrm{ppm}$ and in treated water average value is 1513.3 and $1613.3 \mathrm{ppm}$ (fig. 15). The high concentration of various dissolved salts is reflected in the high TDS value of raw water. $\mathrm{Na}^{+}$concentration in raw water it was found to be 270.6 and $375.6 \mathrm{ppm}$ and for treated water 348 and $309.14 \mathrm{ppm}, \mathrm{K}^{+}$concentration in both raw and treated water varied from 13.7 and 11.8 ppm (fig. 16 and 17).

\section{CONCLUSION}

To conclude we have investigated the filter performance of the AA based filters filled with 10 and $25 \mathrm{~kg} \mathrm{AA}$. It was found that the filter with 10 $\mathrm{kg} \mathrm{AA}$ was better, as it needed to be filled only once daily to be able to meet the water demands of a family. Also its initial capital cost was $60 \%$ lower than that with $25 \mathrm{~kg} \mathrm{AA}$. However, in terms of recurring costs of one liter water (if $A A$ is discarded after single use) the filter with $25 \mathrm{~kg} \mathrm{AA}$ is cheaper to operate by $15 \%$ as compared to the filter with $10 \mathrm{~kg} \mathrm{AA}$. The higher efficiency of the AA in the filter with $10 \mathrm{~kg} \mathrm{AA}$ reflected in its fluoride uptake capacity which was found to be double than that of $25 \mathrm{~kg} \mathrm{AA}$. With a high flow rate of $20 \mathrm{lit}$. $/ \mathrm{h}$, the filter with $10 \mathrm{~kg} \mathrm{AA}$ is suitable for installation at a common place so that 5-6 household living close together can take benefit of the filter.

\section{ACKNOWLEDGEMENT}

Financial help from DST, Govt. of India in the Science for Equity Empowerment and Development Program, Grant No. SP/RD/013/2008 is acknowledged. The authors thank the MITS for providing facilities and support.

\section{REFERENCES}

1. K. Bailey, J.Chilton, E. Dahi, M. Lennon, P. Jackson and J. Fawell, Fluoride in Drinking Water, World Health Organisation, IWA Publishing, London (2006). <http://apps.who.int/iris/bitstream/ 10665/43514/1/9241563192_eng.pdf> (date accessed 20th December, 2012)

2. S. Ayoob and A.K. Gupta, Fluoride in Drinking Water: A Review on the Status and Stress Effects, Critical Reviews in Environmental Science and Technology, 36, 6 (2006), 433-487.

3. A.K Shusheela, Treatise on Fluorosis: 3rd Revised Edition, Publishd by Fluorosis Research \& Rural Development Foundation, Delhi (2007).

4. K.S. Kothari, Fluorosis Affecting Health/Teeth of Children and People in Rural Rajasthan, http://www.journa listkothari.com/DEFAULT.htm (date accessed 23rd Sept. 2012). 
5. Meenakshi, R.C.Maheshwari, Fluoride in Drinking Water and its Removal, Journal of Hazardous Materials, 137, 1 (2006) 456-463.

6. S. K. Sharma, Toxicity of Fluoride in Parts of Indian Subsurface Water, Environmetal and Ground Water Pollution (2002). $<$ http://www.bvsde.paho.org/bvsacd/cd27/ sharmask.pdf>.

7. S. P. S Teotia, M. Teotia and K.P. Singh, Highlights of Forty Years of Research on Endemic Skeletal Fluorosis in India, 4th International Workshop on Fluorosis Prevention and Defluoridation of Water, Colombo, Sri Lanka, 2-6th March, (2004) Edited by: Eli Dahi.

8. Y. Si and B. Zhang, Epidemiology Study of Dental Fluorosis in China, 4th International Workshop on Fluorosis Prevention and Defluoridation of Water, Colombo, Sri Lanka, 2-6th March, (2004) Edited by: Eli Dahi.

9. A.K.Susheela, Fluorosis Management Programme in India, Current Science, 77, 10 (1999) 1250-1256.

10. A.K.Lahiry, Fluorspar Deposits of India, 42, 4 (1974). <http://www.new.dli.ernet.in /rawdataupload/upload/insa/INSA_1/2000 5bae 263.pd> (date accessed 2nd March 2013).

11. P.Singh, B.Rani, U.Singh, R.Maheshwari, Fluoride Contamination in Groundwater of Rajasthan and its Mitigation Strategies, Journal of Pharmaceutical and Biomedical Science, 6, 6, (2011) 1-12.

12.P. Eswar and C.G. Devaraj, Water defluoridation: Field Studied in India, 03, 02 (2011). <http://www.nacd.in/ijda/ volume-03-issue-02/120-water-

defluoridation-field-studies-in-india>. (date accessed 2nd March 2013).

13. C. Venkobachar, L. lyengar and A.K Mudgal, Household Defluoridation of Drinking Water Using Activated Alumina, Proceedings of the 2nd International Workshop on Fluorosis Prevention and Defluoridation of Water, Nazreth, Ethiopia, 19-25th Nov. (1997), Edited by E. Dahi, and J. M. Nielsen, 138-145.
14. A.K.Vaish and P.Vaish, A Case Study of Fluorosis Mitigation in Duangarpur District, Rajasthan, 3rd International Workshop on Fluorosis Prevention and Defluoridation of Water, Chiang Mai, Thailand, 24th Nov. (2000) 97-104.

15. G. Karthikeyan, S. Meenakshi and B.V Apparao, Defluoridation Properties of Activated Alumina, 2nd International Workshop on Fluorosis Prevention and Defluoridation of Water, Nazreth, Ethiopia, 19-25th Nov. (1997) Edited by Eli Dahi \& Joan Maj Nielsen, 78-82.

16. L. lyenger, Defluoridation of Water Using Activated Alumina Technology: Studies at IIT Kanpur, A Report for UNICEF, New Delhi 2005.

17. Design of Filter for Fluoride and Bacteria Removal. <http://www.inrem.in/fluorosis/ pdf/Filter.pdf $>$ (date accessed 20th December, 2012).

18. Draft Specifications for Domestic Defluoridation Filter Unit and Activated Alumina for Defluoridation, UNICEF (2004).

19. M. Srimurali and G.Karthikeyan, Defluoridation of Water and Household Application- A Study, Proceeding of the Twelfth International Water Technology Conference, Alexandria, Egypt (2008) 153-163.

20. M. Srimurali and G.Karthikeyan, Defluoridation of Water and Household Application- A Study, Proceeding of the Twelfth International Water Technology Conference, Alexandria, Egypt (2008) 153-163.

21. N.V. Dzung, H.H. Phong, N.N. Long, N.T. Qang and P. Waldemor, Domestic Defluoridation of Water Using Locally Produced Activated Alumina, Proceeding of the 4th International Workshop on Fluorosis Prevention and Defluoridation of Water Colombo, Sri Lanka, 2-6th March (2004), Edited by: Eli Dahi.

22. V.S. Chauhan, P.K. Dwivedi, L. lyengar, Investigation on Acitavted Alumina Based Domestic Defluoridation Units, Journal of Hazardous Materials, B139, 2007, 103107. 
23. R. Agrawal, K. Margandan, M.K. Mishra, K. Singh, R. Acharya, S. Sharma, K. Qanungo, Fluoride Removal Using Activated Alumina-A Case Study of Bhooma Chhota Water, (communicated).

24. R. Agrawal, K. Margandan, M.K. Mishra, K. Singh, R. Acharya, S. Sharma, K. Qanungo, Fabrication and Testing of a Low Cost Activated Alumina Based Domestic Defluoridation Unit Using a Caramic Cartridge, (communicated).

25. R. Agrawal, K. Margandan, M.K. Mishra, K. Singh, R. Acharya, S. Sharma, K. Qanungo, Improvement of User Friendliness of a Simple Domestic Defluoridation Unit Using Activated Alumina, (communicated).

26. W.G. Nawlakhe, K.R. Bulusu, Defluoridation of Water by Batch Operation, Indian Journal of Environmental Health 30, 3 (1988) 262299.

27. Y.C.Wu, A. Nitya, Water Defluoridation by Activated Alumina, Journal of Environmental Engineering Division, 105, 2 (1979) 357-367.

28. S.George, P.Pandit, A.B.Gupta, Residual Aluminium in Water Defluoridated Using Activated Alumina- Modeling and Simulation Studies, Water Research, 44, 10 (2010) 3055-3064.

29. O. Hao and C. Huang, Adsorption Characteristics of Fluoride onto Hydrous Alumina, Journal of Environmental Engineering, 112, 6, 1986, 1054-1069.

30. P.L.Bishop and G.Sanaoucy, Fluoride Removal From Drinking Water by Fluidized Activated Alumina Adsorption, Journal American Water Works Association, 70, 10 (1978) 554-559.

31. S.Ghorai, K.K. Pant, Investigations on the Column Performance of Fluoride adsorption by Activated Alumina in a Fixed- Bed, Chemical Engineering Journal 98 (2004) 165-173.

32. a) Indian Standards for Drinking Water, ISO 10500 <http://hppcb.gov.in/eiasorang/spec.pdf> b) Indian Standards for Drinking Water, ISO 10500 (1992) <http://hppcb.gov.in/ eiasorang/spec.pdf> (date accessed 20th December, 2012)

PERIÓDICO TCHÊ QUÍMICA • www.periodico.tchequimica.com • Vol. 10 N. 19 • ISSN 1806-0374 (impresso) • ISSN 1806-9827 (CD-ROM) • ISSN 2179-0302 (meio eletrônico) 
Table 1. Cost of Components of 51 liter Intermediate Filter with Ceramic Cartridge

\begin{tabular}{c|c|c}
\hline Filter Parameters & 10 kg AA Four candle filter & 25 kg AA Four candle filter \\
\hline $\begin{array}{c}\text { Activated Alumina } \\
\text { Q Rs. } 116 / \$ 2.10 / \mathrm{kg}\end{array}$ & Rs. $1160 / \$ 21.09$ & Rs. 2900/\$ 52.72 \\
\hline Drum @ Rs. 200/\$ 3.63 & Rs. 200/\$ 3.63 & Rs. 200/\$ 3.63 \\
\hline Big Bucket @ Rs. 265/\$4.81 & Rs. $265 . / \$ 4.81$ & Rs. $265 / \$ 4.81$ \\
\hline $\begin{array}{c}\text { Ceramic Cartridge } \\
\text { Q Rs. } 280 / \$ 5.09\end{array}$ & Rs. $1120 / \$ 20.36$ & Rs. $1120 / \$ 20.36$ \\
\hline $\begin{array}{c}\text { Outlet valve @ Rs. } \$ 0.545 \\
\text { Total Cost Rs. } / \$)\end{array}$ & Rs. $30 / \$ 0.545$ & Rs. $30 / \$ 0.545$ \\
\hline
\end{tabular}

Table 2. Characteristics of filters with different quantities of activated alumina

\begin{tabular}{|c|c|c|}
\hline+2 & 10 & 25 \\
\hline Capacity (lit.) & 40 & 16 \\
\hline Depth of A.A covering ceramic cartridge & $7.4 \mathrm{~cm}$ & $27.6 \mathrm{~cm}$ \\
\hline Depth of A.A in upper chamber & $16.7 \mathrm{~cm}$ & $36.5 \mathrm{~cm}$ \\
\hline$\overline{\text { Bed Vol. (lit) }}$ & 13.5 & 33.78 \\
\hline$\overline{\mathrm{EBCT}(\min )}$ & 39.35 & 56.3 \\
\hline Diameter of upper chamber & $40.6 / 32 \mathrm{~cm}$ & $41 / 32 \mathrm{~cm}$ \\
\hline Time (min)for emptying of the filter (brimful) & 116 min & 103 min \\
\hline Liters per hour & $20.6 \mathrm{lit} / \mathrm{h}$ & $10 \mathrm{lit} / \mathrm{h}$ \\
\hline$\overline{F U C(\mathrm{mg} / \mathrm{kg})}$ & 722.7 & 396.24 \\
\hline No. of refills required per day water & $1 / 2$ & 2 \\
\hline $\begin{array}{l}\text { Vol. of safe water (lit.) } \\
\left(1^{\text {st }} \text { Cycle }\right) @ 2.4 \text { ppm F } \\
\end{array}$ & 3300 & 3900 \\
\hline No. of filter refills of safe water & 82.5 & 243.75 \\
\hline Time before $1^{\text {st }}$ regeneration & 5 months 15 days & 4 months 10 days \\
\hline Capital Filter Cost (Rs./\$) & $2775 / 50.454$ & $4515 / 82.09$ \\
\hline $\begin{array}{l}\text { Cost of defluoridated water per liter (for } 1^{\text {st }} \\
\text { cycle) in Rs } \$ \$ \\
\text { (Consider capital cost of the filter) }\end{array}$ & $0.84 / 0.015$ & $1.15 / 0.0209$ \\
\hline $\begin{array}{l}\text { Recurring cost of } 1 \text { liter water (if } A A \text { is } \\
\text { discarded after Single use in paisa/ } \$ \text { ) }\end{array}$ & $35.15 / 0.0063$ & $29.74 / 0.0054$ \\
\hline
\end{tabular}




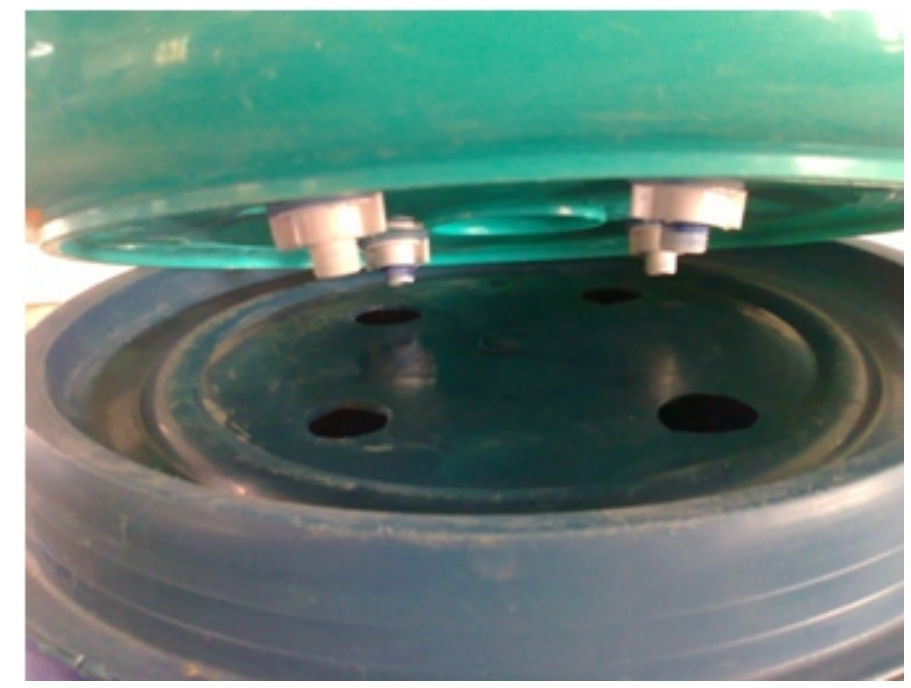

Figure 1. Photograph of Middle Portion of the Filter

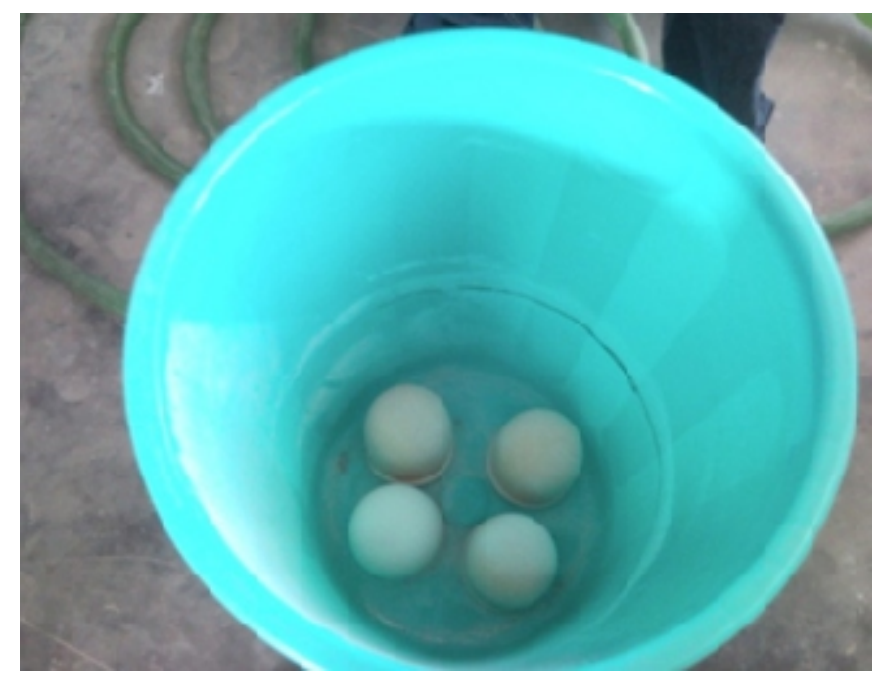

Figura 2. Photograph of the inside of the filter with four ceramic cartridges (without the $A A$ ) 


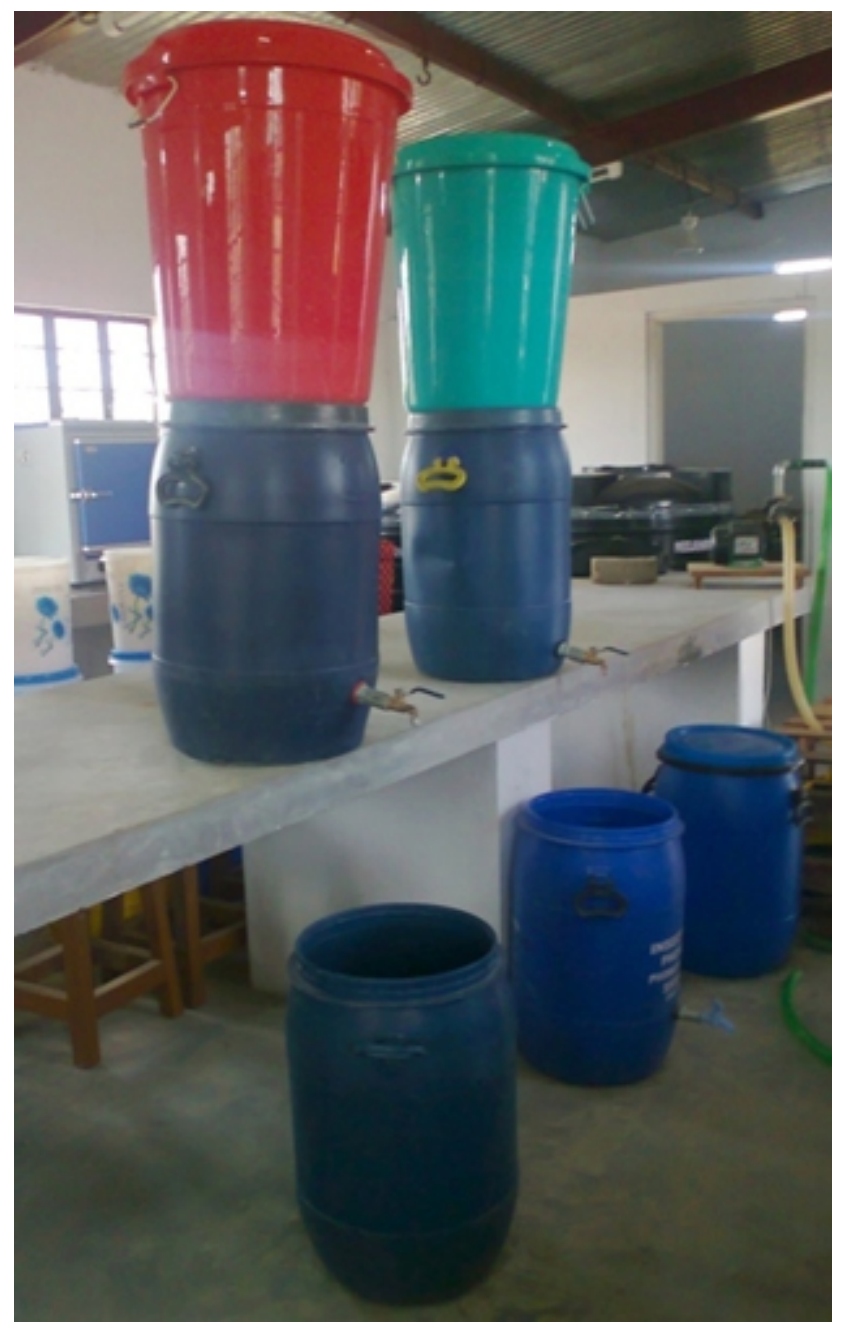

Figura 3. Photo of the fabricated filter with four ceramic candles with Activated Alumina

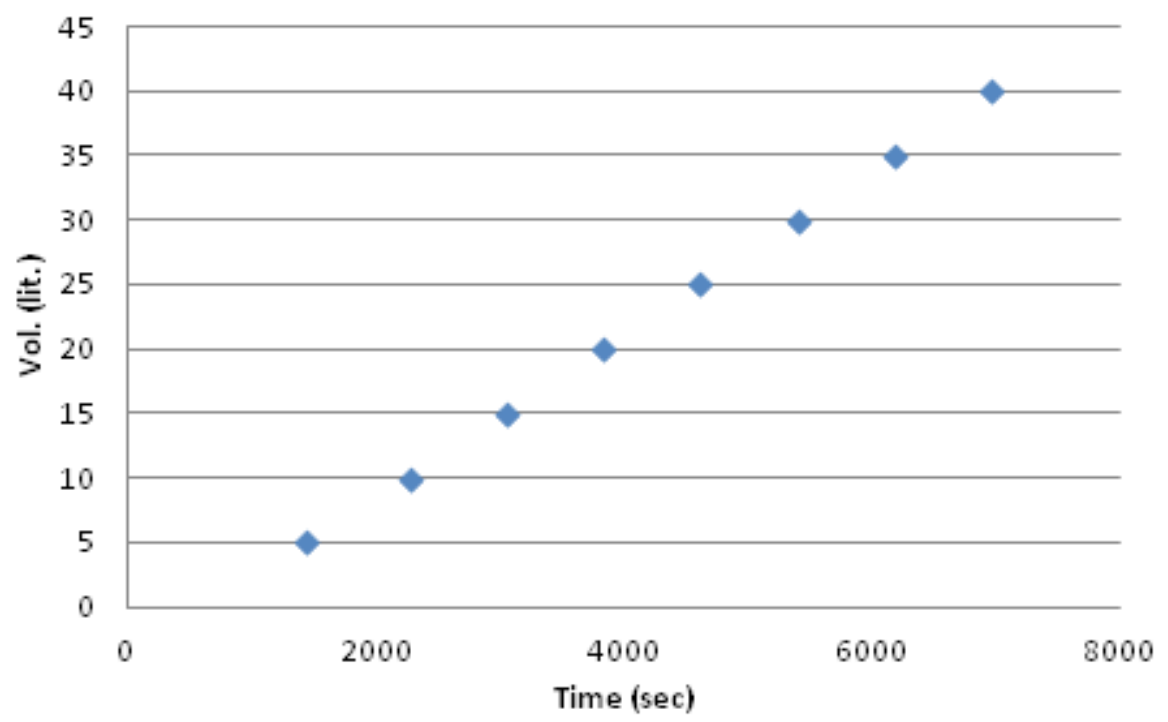

Figura 4. Flow rate of filter with $10 \mathrm{~kg} \mathrm{AA}$

PERIÓDICO TCHÊ QUÍMICA • www.periodico.tchequimica.com • Vol. 10 N. 19. - ISSN 1806-0374 (impresso) • ISSN 1806-9827 (CD-ROM) • ISSN 2179-0302 (meio eletrônico) 


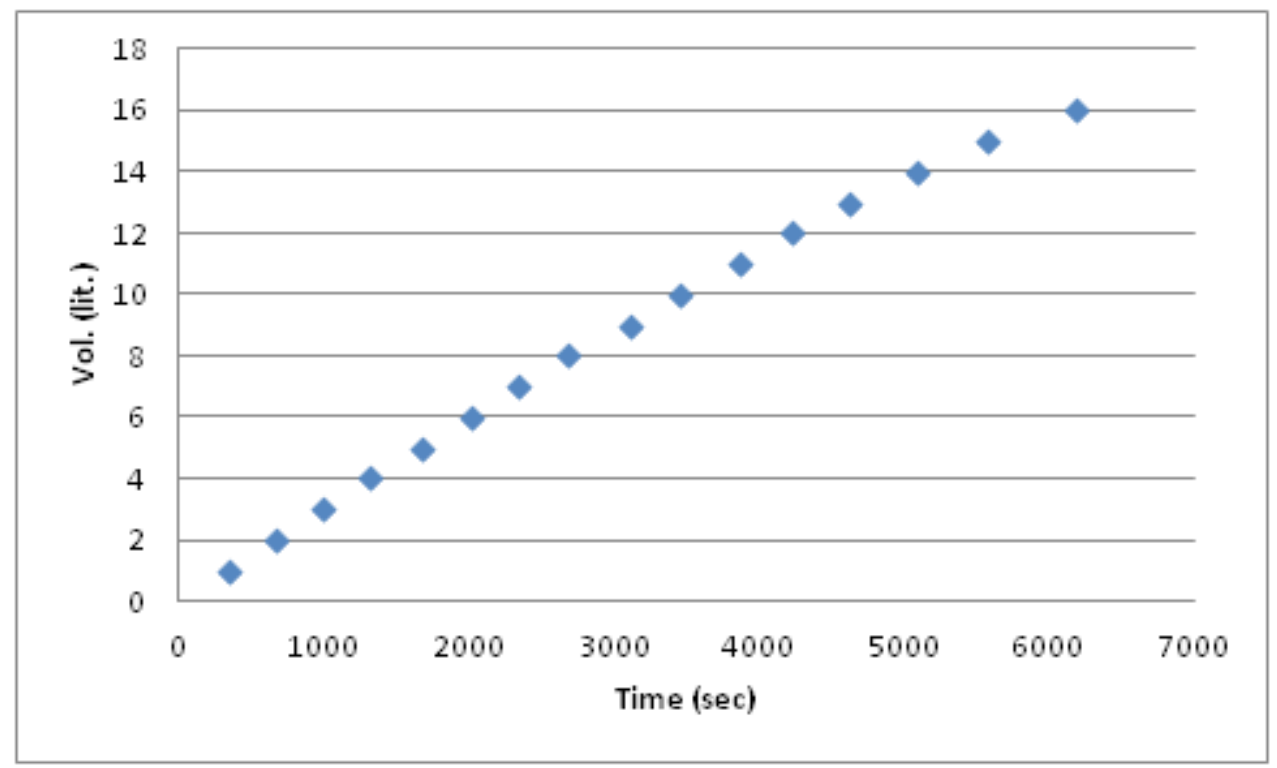

Figura 5. Flow rate of filter with $25 \mathrm{~kg} \mathrm{AA}$

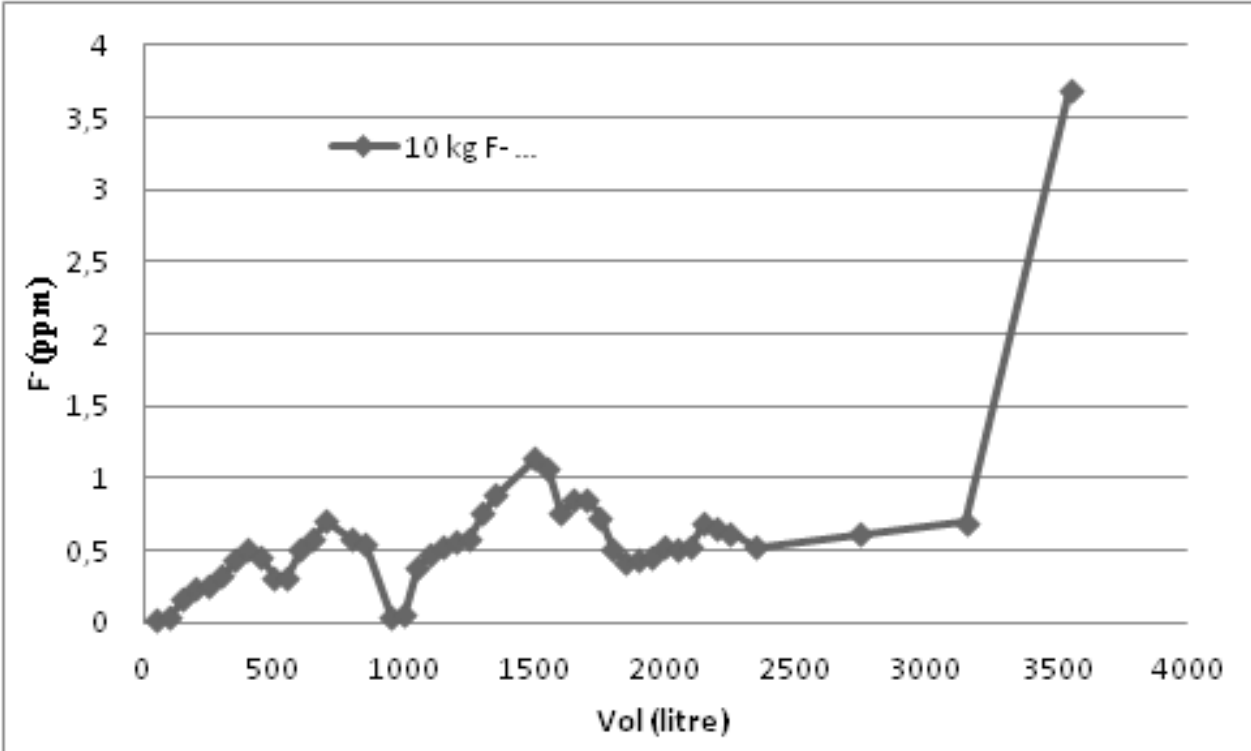

Figura 6. Breakthrough profile of filter with $10 \mathrm{~kg} A A @$ average inlet fluoride conc. 2.94 ppm

PERIÓDICO TCHÊ QUÍMICA • www.periodico.tchequimica.com • Vol. 10 N. 19 • ISSN 1806-0374 (impresso) • ISSN 1806-9827 (CD-ROM) • ISSN 2179-0302 (meio eletrônico) 


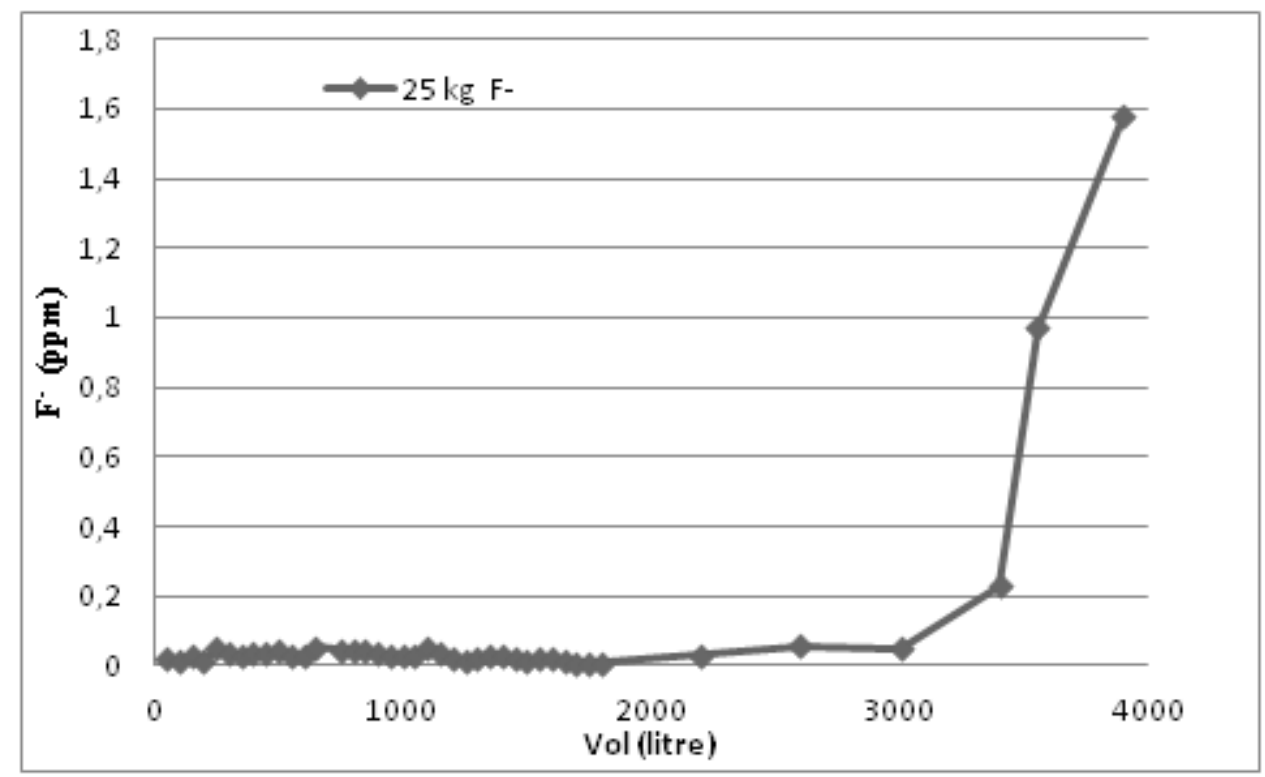

Figura 7. Breakthrough profile of filter with $25 \mathrm{~kg} \mathrm{AA@} \mathrm{average} \mathrm{inlet} \mathrm{fluoride} \mathrm{conc.3.29} \mathrm{ppm}$

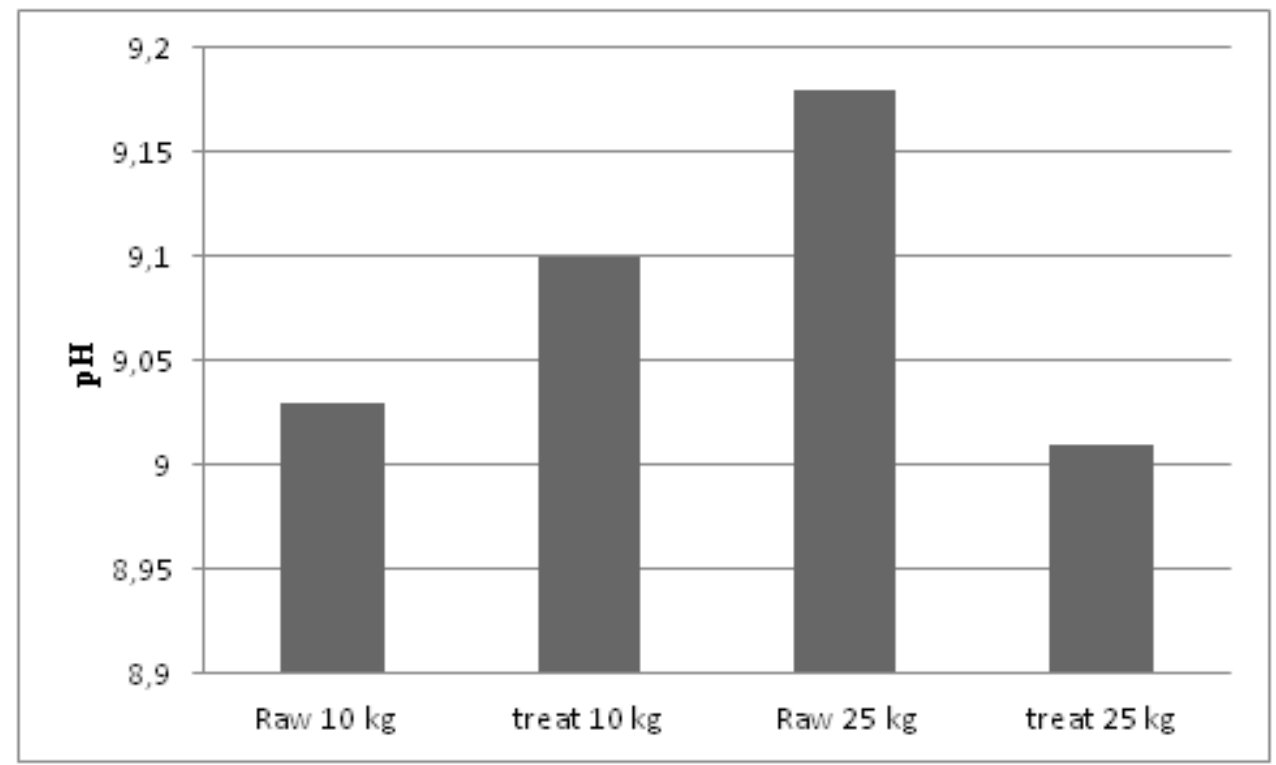

Figura 8. Comparative average $\mathrm{pH}$ values of raw and treated water from filters with 10 and $25 \mathrm{~kg} \mathrm{AA}$ 


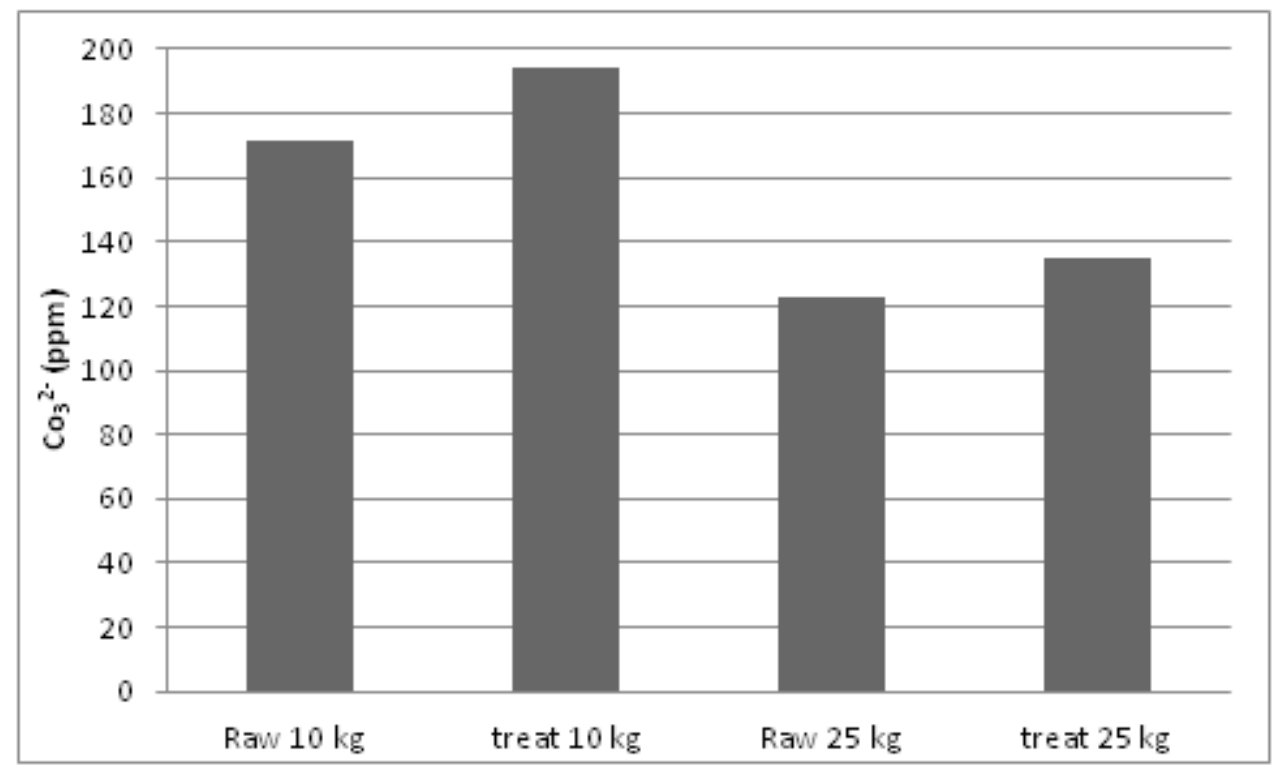

Figura 9. Comparative average Carbonate values of raw and treated water from filters with 10 and $25 \mathrm{~kg} \mathrm{AA}$

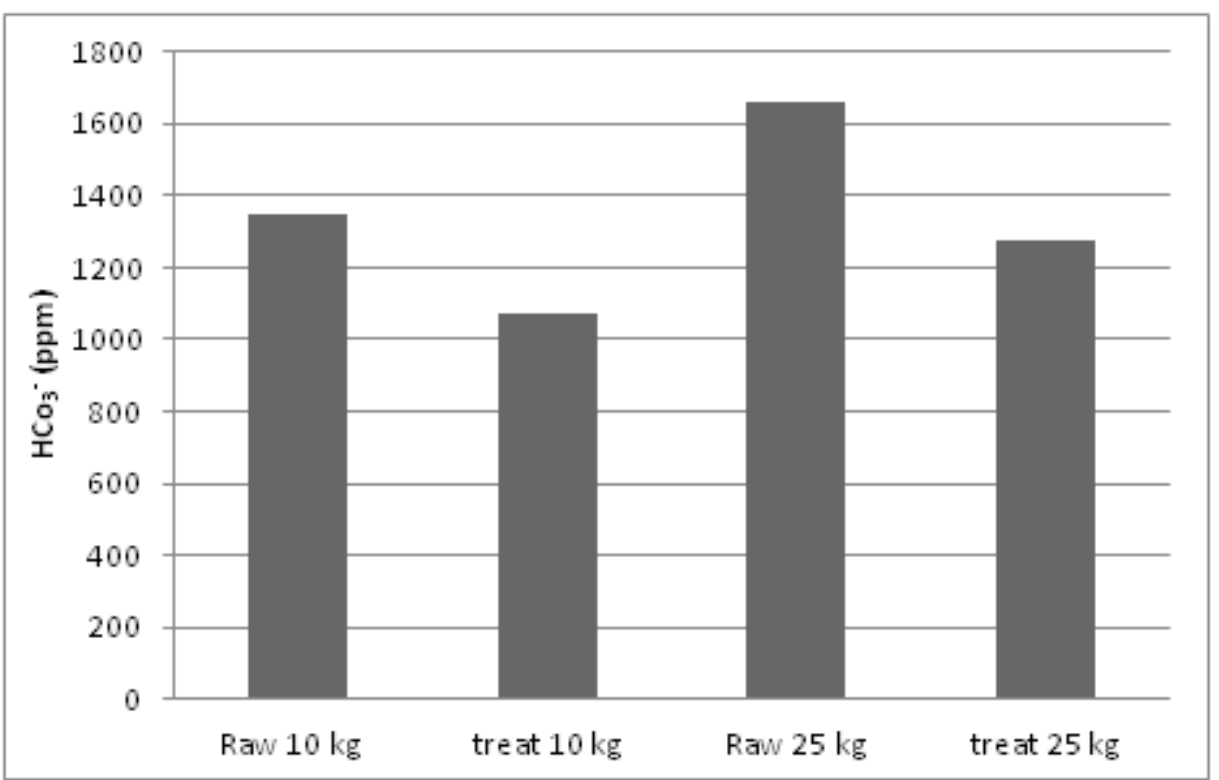

Figura 10. Comparative average Bicarbonate values of raw and treated water from filters with 10 and $25 \mathrm{~kg} \mathrm{AA}$ 


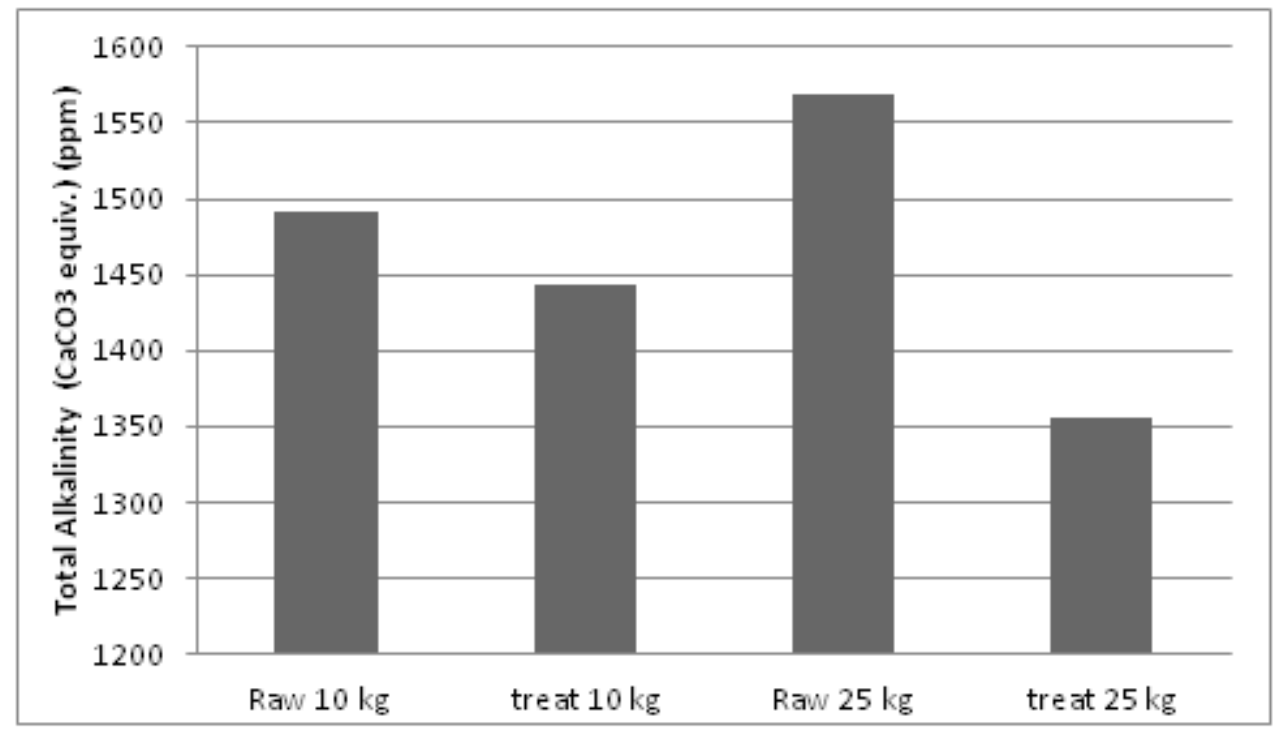

Figura 11. Comparative average Total Alkalinity values of raw and treated water from filters with 10 and $25 \mathrm{~kg} A A$

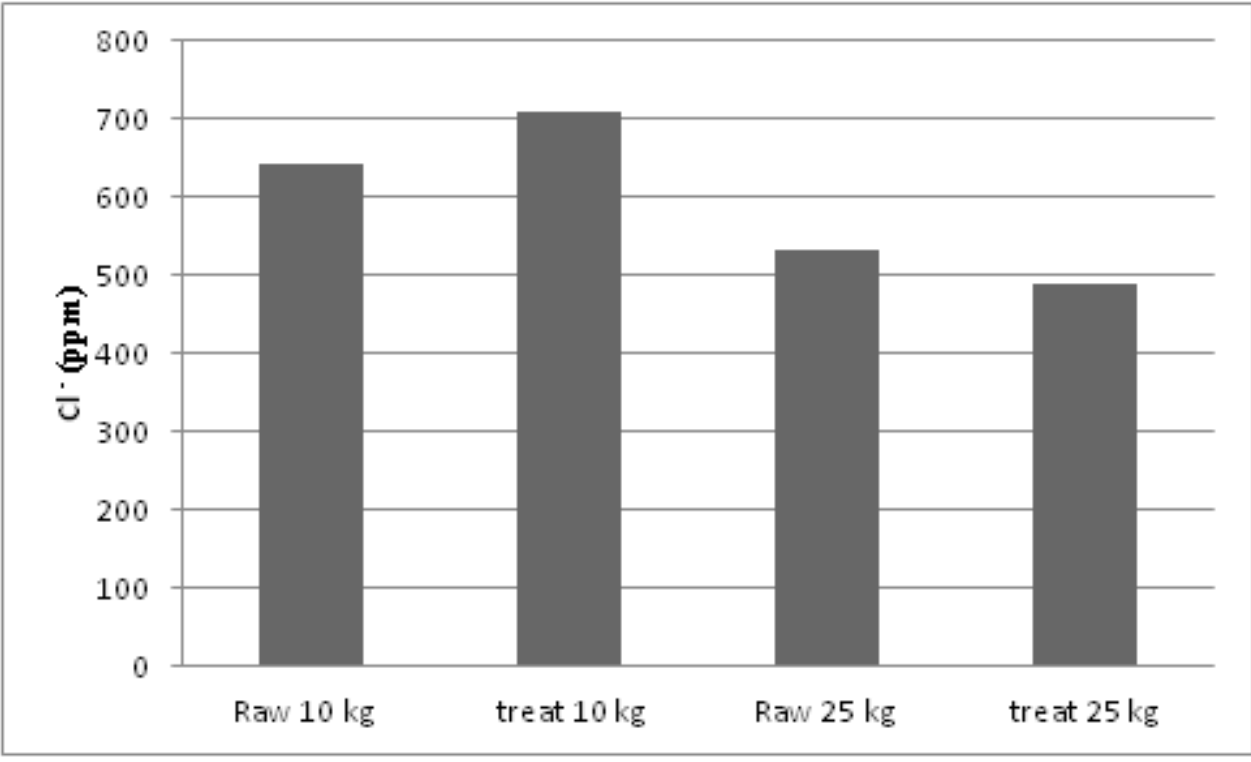

Figura 12. Comparative average $\mathrm{Cl}$ - values of raw and treated water from filters with 10 and $25 \mathrm{~kg} \mathrm{AA}$ 


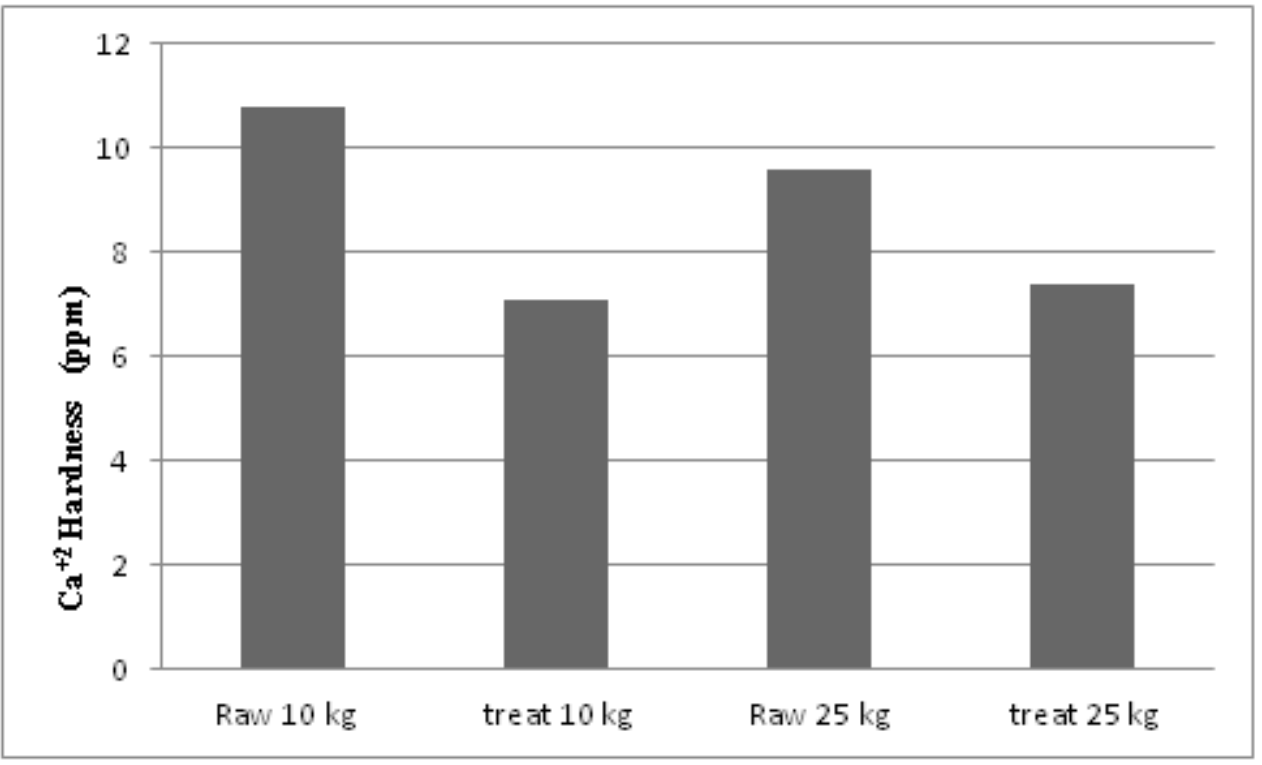

Figura 13. Comparative average Ca+2 Hardness values of raw and treated water from filters with 10 and $25 \mathrm{~kg} \mathrm{AA}$

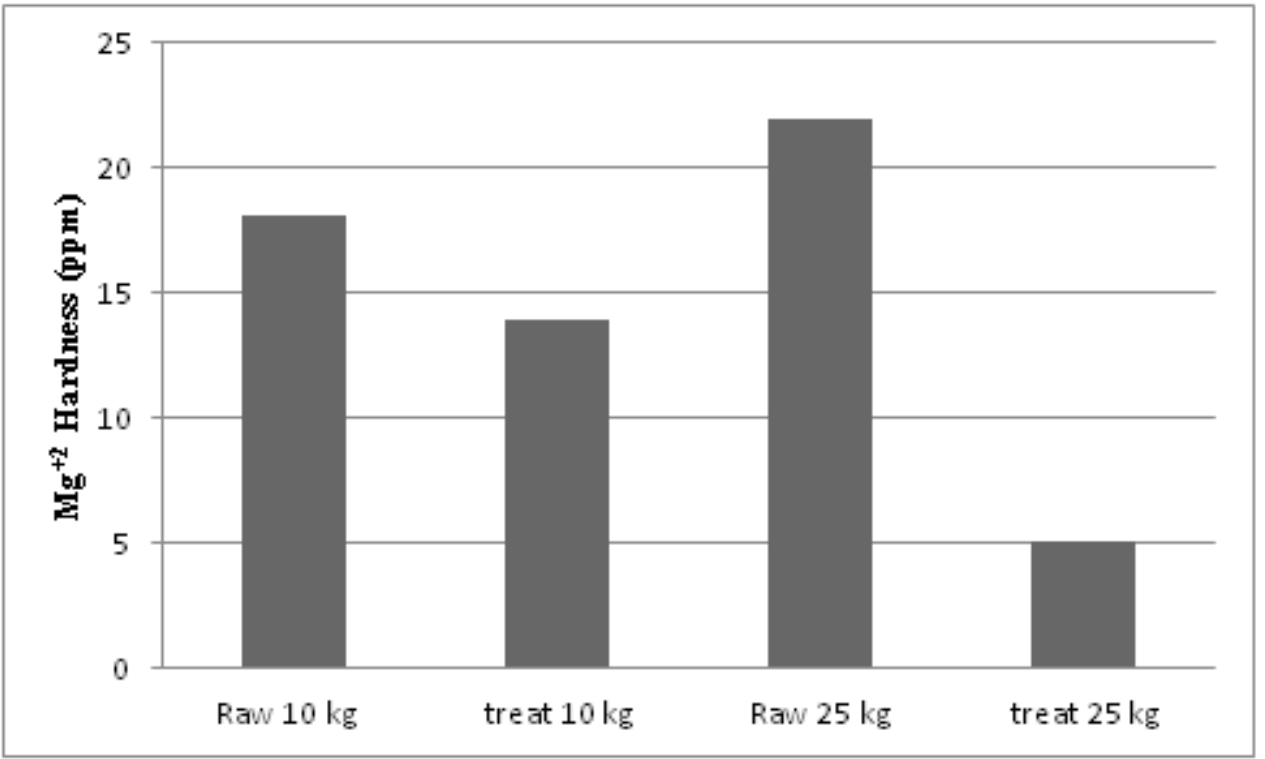

Figura 14. Comparative average $\mathrm{Mg}+2$ Hardness values of raw and treated water from filters with 10 and $25 \mathrm{~kg} A A$ 


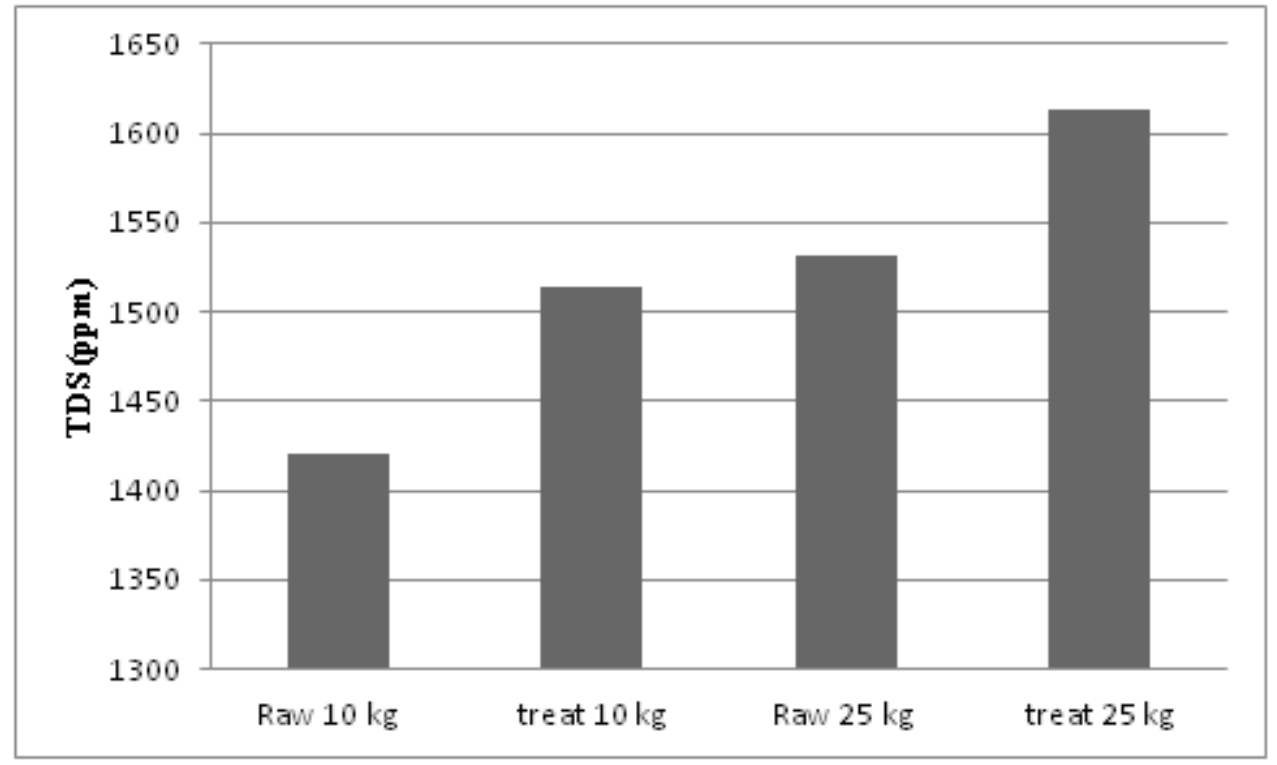

Figura 15. Comparative average TDS values of raw and treated water from filters with 10 and $25 \mathrm{~kg} \mathrm{AA}$

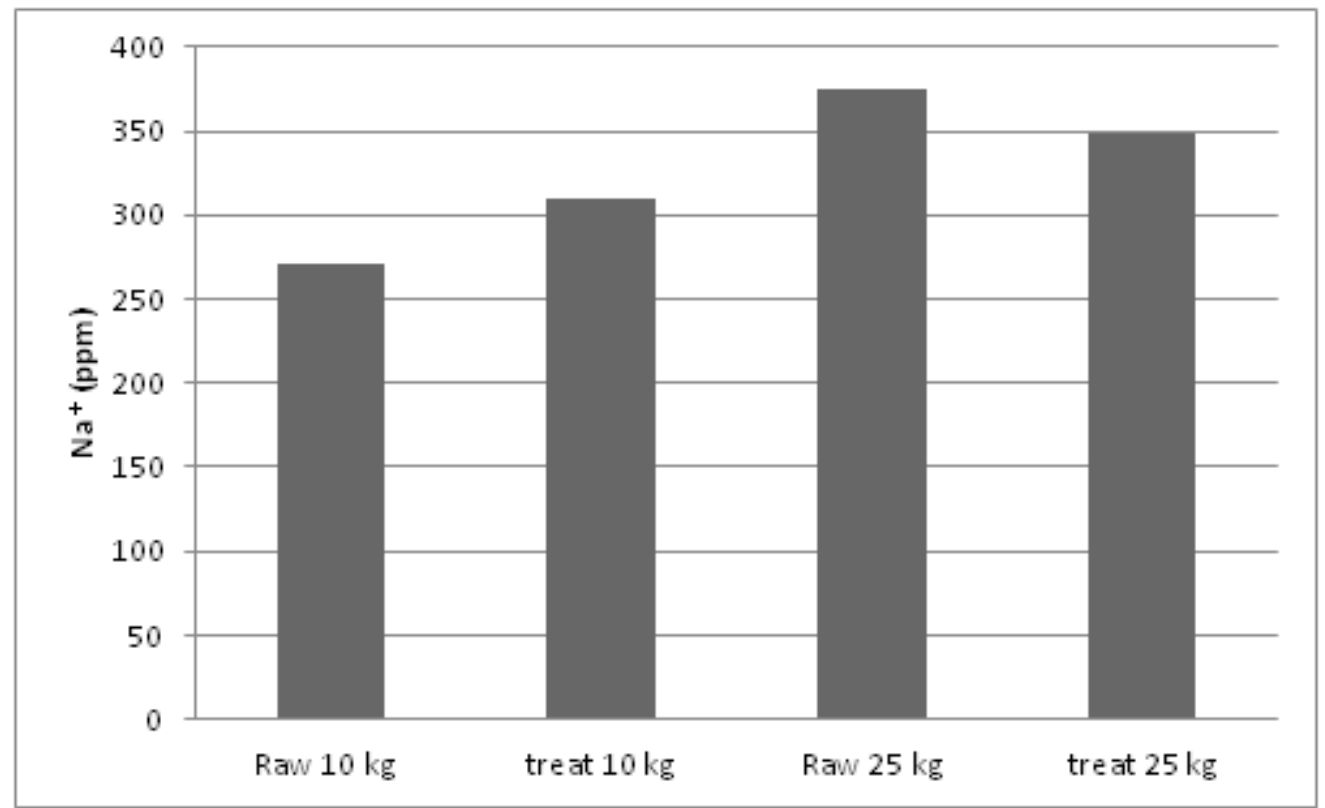

Figura 16. Comparative average Sodium values of raw and treated water from filters with 10 and $25 \mathrm{~kg} \mathrm{AA}$ 


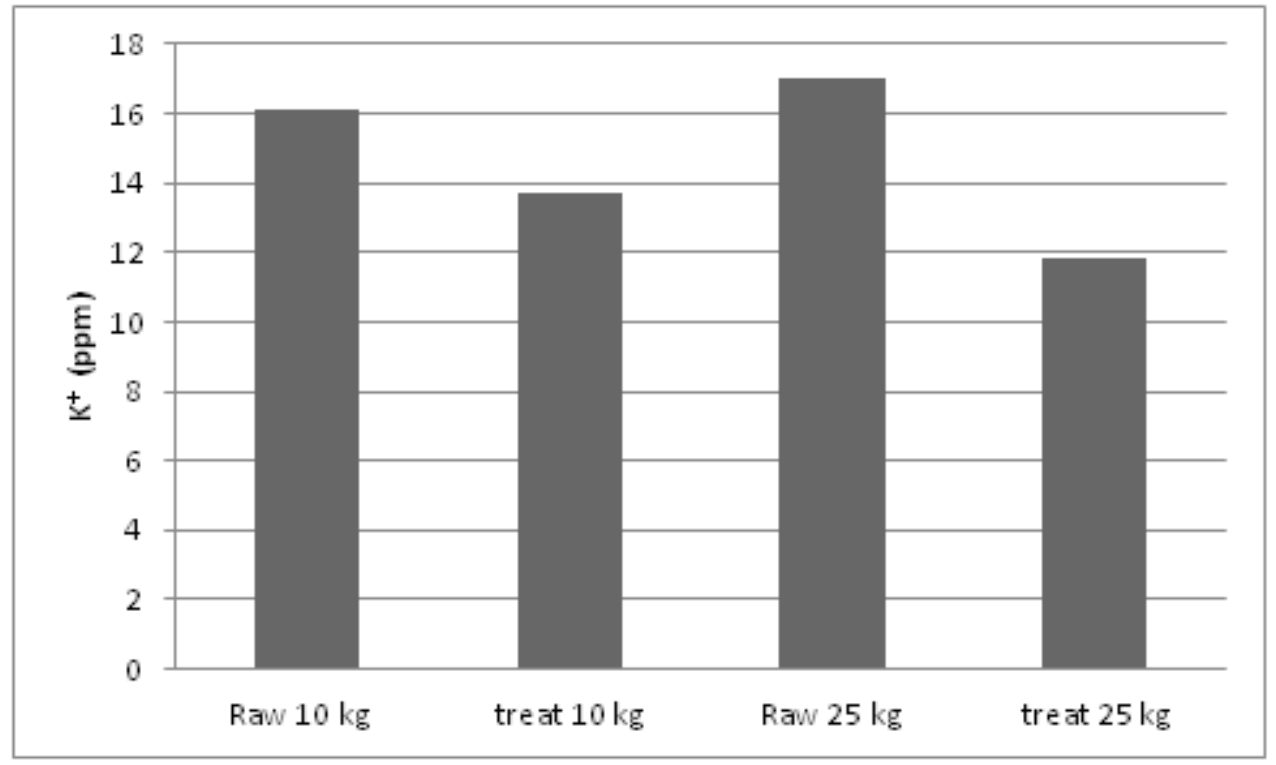

Figura 17. Comparative average Potassium values of raw and

treated water from filters with 10 and $25 \mathrm{~kg} \mathrm{AA}$

PERIÓDICO TCHÊ QUÍMICA • www.periodico.tchequimica.com • Vol. 10 N. 19. - ISSN 1806-0374 (impresso) • ISSN 1806-9827 (CD-ROM) • ISSN 2179-0302 (meio eletrônico) (C) 2011. Porto Alegre, RS. Brasil

OPEN ACCESS. This article is licensed under a Creative Commons Attribution 4.0 (CC BY 4.0) International License, which permits use, sharing, adaptation, distribution, and reproduction in any medium or format, as long as you give appropriate credit to the original author(s) and the source, provide a link to the Creative Commons license, and indicate if changes were made. The images or other third-party material in this article are included in the article 's Creative Commons license unless indicated otherwise in a credit line to the material. If material is not included in the article's Creative Commons license and your intended use is not permithed by stalulory regulation exceeds the permitted use, you will need to obtain permission directly from the copyright holder. To view a copy of his license, vist htp.//creativecommons.org/icenses/by/4.0/. 